\title{
Influence of adult diet on biological parameters of the housefly, Musca domestica L. (Diptera: Muscidae)
}

\author{
Haffizou Ganda ${ }^{1,3^{*}}$ (D), Hermann A. Abihona', Elisabeth T. Zannou-Boukari ${ }^{1}$, Marc Kenis ${ }^{2}$, \\ Christophe A. A. M. Chrysostome ${ }^{3}$ and Guy A. Mensah ${ }^{4}$
}

\begin{abstract}
Background: Housefly (Musca domestica L. 1758) larvae are used in various parts of the world for animal feeding either by exposing substrates for natural oviposition or in industrial systems involving an adult rearing unit to produce eggs that are then placed in a substrate suitable for larval development. In order to develop M. domestica rearing system in Benin, effects of five types of food (pineapple, papaya, banana, honey, and a mixture of milk + sugar) on some biological parameters (female fecundity, adult mortality, egg hatching, pupation, and emergence time and rates) have been evaluated.

Results: Flies fed with pineapple and milk + sugar showed the highest fecundity (respectively 321 and 325 eggs per female within 10 days). Adult mortality rates decreased significantly with flies fed with honey (27\% in 10 days) and milk + sugar (37\%) compared to flies fed on local fruits (57 to 62\%). Only minor differences were observed between the five foods in egg hatching, pupation and emergence rates.

Conclusion: This study showed that pineapple can be used to feed $M$. domestica instead of the conventional and more expensive milk + sugar mixture without major impact on the efficiency of $M$. domestica rearing.
\end{abstract}

Keywords: Musca domestica, Local fruits, Fecundity, Mortality, Animal protein

\section{Introduction}

The housefly (Musca domestica L. 1758) is mainly known for its nuisances as a disease vector. This fly species is characterized by large populations and a high fecundity, which makes it a human and animal health problem (Hogsette et al. 2001; Scott et al. 2000). However, the ability of $M$. domestica to reproduce quickly can also be used to produce larvae for the feeding of poultry and fish. Indeed, the high costs of dietary protein are a hindrance to livestock development in Africa, particularly fish and poultry (Kenis et al. 2014). This leads

\footnotetext{
* Correspondence: gandahaffiz@gmail.com

'Laboratory of Agricultural Entomology (LEAg), Faculty of Agronomic

Sciences, University of Abomey-Calavi, Abomey-Calavi, Republic of Benin ${ }^{3}$ Laboratory of Aviculture and Zoo-economy Research, Faculty of Agronomic Sciences, University of Abomey-Calavi, Abomey-Calavi, Republic of Benin Full list of author information is available at the end of the article
}

to the search for other cheap sources of protein that are available and accessible to all. In comparison with other insect species, larvae of $M$. domestica (maggots) have been widely studied as a potential source of protein for animals (Aniebo et al. 2008; Fasakin et al. 2003; Kenis et al. 2018; Newton et al. 2005; Pastor et al. 2015).

Animal wastes, agri-food wastes, and decaying fruits are the main food sources for flies in nature (Newton et al. 2005; Pomalégni et al. 2016; Sanou et al. 2018). These substrates can therefore be used for the production of fly larvae in free oviposition systems as described in Koné et al. (2017). In Benin, almost $6 \%$ of the farmers feed their poultry with fly larvae, at least occasionally, mostly by exposing substrates to naturally occurring flies (Pomalégni et al. 2016; Pomalégni et al. 2017). However, fly larvae can also be obtained using an adult rearing unit to produce eggs that are then inoculated in a 
substrate suitable for larval development (Čičková et al. 2015; Drew and Pieterse, 2015; Pastor et al. 2015; Wang et al. 2013). The rearing systems of adult flies in cages for the production of larvae have the advantage of reducing the risk of increasing fly populations in the nature and therefore their impact on human health. Systems for breeding $M$. domestica in wire cages with several food sources (sugar-milk mixture in the same proportions, honey and meat broth) are described in Čičková et al. (2015), Čičková et al. (2012), Ortiz et al. (2016), and Kenis et al. (2018).

Food quality greatly influences life history traits such as survival, development, and fecundity of an insect in nature (Bong et al. 2014). Carbohydrates are generally the main source of energy for insects, while proteins play a major role in their reproduction and fecundity (Lardies et al. 2004). In fly rearing, the quality of adult food is essential to ensure that females are capable of producing large amounts of eggs and vigorous larvae (Pastor et al. 2015). However, the different types of food used for breeding $M$. domestica (sugar, powder milk, honey, sometimes yeast, and meat) are expensive and often not accessible to small farmers and small- and mediumsized production units; hence, the need to look for new sources of locally available and accessible foods.

The aim of this study was to test different types of food that are locally available and applicable to $M$. domestica under breeding conditions and analyze their effect on the biological parameters that are essential for setting up an efficient $M$. domestica adult rearing system for larvae production in Benin.

\section{Materials and methods Material}

The tests were conducted at the farm of the Faculty of Agronomic Sciences, Abomey-Calavi University in Benin (latitude 6 24'54.6912' $\mathrm{N}$ and longitude $2^{\circ} 20^{\prime} 40.1892^{\prime \prime}$ E) from January to September 2017. The different fly colonies used were obtained in January by exposing fermented corn bran and soybean bran outdoors to naturally occurring flies. In the following days, the substrates containing larvae were placed in wire netting cages until fly emergence. Emerged $M$. domestica adults were identified with a stereomicroscope using identification keys (Delvare and Aberlenc, 1986), isolated in $60 \times 60 \times 80 \mathrm{~cm}$ wire netting cages and fed with a powder milk and sugar mixture. Maize bran was placed in the cages as laying substrate in order to obtain a new generation of larvae, pupae, and adults. Flies of third generation were used for experimentation.

\section{Musca domestica rearing and assessment of biological parameters}

Adults of $M$. domestica were reared in gauze cages (about 100 adults per cage of $60 \times 60 \times 80 \mathrm{~cm}$ ). They were provided with water and fed with different foods to assess the food influence on biological parameters of adult of $M$. domestica. The oviposition substrate consisted of fermented poultry manure covered by yellow fabric (Charlton et al. 2015). The cages were placed outdoors under a roof to avoid the effects of rain and direct sun. Temperatures during tests varied between 24 and $32{ }^{\circ} \mathrm{C}$ when relative humidity varied from 60 to $70 \%$.

The tests consisted in a comparison between biological parameters of flies fed on two conventional types of food (honey and mixture of 50\% dry milk and 50\% sugar) and that of flies fed on three local fruits: banana (local variety), pineapple (variety "Pain de Sucre"), and papaya (variety Sunrise). The approximate nutritional composition of the foods used in the experiments is presented in Table 1 (Stadlmayr et al. 2010). Honey and mixture of dry milk and sugar were renewed weekly while fruits were renewed every 3 days. The pulps of the three fruits were mixed in an electric mixer to obtain a pasty substrate easily consumable by adult flies. Fifty grams of each type of food were used per treatment and replication.

\section{Biological parameters' collection}

To assess fecundity, hundreds of freshly emerged adults (sex ratio 1:1) were placed in cages, and eggs were collected and counted daily from the yellow fabric that covered poultry manure for 10 days. Adult mortality was recorded daily, as well as the sex of the dead flies. Fifty eggs per replicate were incubated on a substrate (humid maize bran) in a Petri dish for monitoring the development time. Eggs hatched, and larvae and pupae were monitored until the emergence of adults. All tests were conducted according to a completely randomized design with six repetitions and five types of food as treatment (honey, mixture of dry milk and sugar, banana, pineapple, and papaya) during the period October 2016 to March 2017 at the farm of the Faculty of Agricultural Sciences of the University of Abomey-Calavi in Southern Benin. For each replicate, observations were done in parallel for the five rearing systems to avoid a potential influence of climatic conditions on the biological parameters.

Data collected during this study included fecundity (number of eggs laid per female), adult mortality, the number of eggs hatched after incubation, the number of pupae obtained, and the number of flies that emerged by type of food. Data collection for female fecundity and adult mortality started $24 \mathrm{~h}$ after adult emergence and were measured daily during 10 days. The fecundity per female was estimated by dividing the total number of eggs collected by the number of live females in the cage, taking into account the daily mortality and the sex of dead flies. The rate of hatched eggs was estimated by 
Table 1 Nutrients content of food used to feed housefly adults

\begin{tabular}{llllll}
\hline Nutrients & Pineapple & Banana & Powder milk + white sugar & Honey & Papaya \\
\hline Energy $(\mathrm{Kcal} / 100 \mathrm{~g})$ & 56 & 100 & 430.5 & 322 & 38 \\
Protein $(\mathrm{g} / 100 \mathrm{~g})$ & 0.4 & 1.3 & 12.65 & 0.3 & 0.5 \\
Carbohydrate available $(\mathrm{g} / 100 \mathrm{~g})$ & 12.1 & 22.2 & 64.9 & 0.2 & 0 \\
Fat $(\mathrm{g} / 100 \mathrm{~g})$ & 0.3 & 0.3 & 13.4 & 0 & 0.1 \\
Fibre $(\mathrm{g} / 100 \mathrm{~g})$ & 1.4 & 1.9 & 0 & 1.9 \\
\hline
\end{tabular}

Source: Stadlmayr et al. 2010

counting the number of larvae 3 days after incubation. Pupation and adult emergence rates estimation started respectively the 5th day after egg incubation and the 4th day after pupation and lasted 5 days for each parameter. Daily pupation rate was calculated by dividing the number of pupae by the initial number of larvae introduced. Adult emergence rate was determined by dividing the number of emerged adults by the total number of pupae formed. Daily mortality of $M$. domestica adults was estimated by dividing the cumulative number of dead adults each day by the number of initial adults in the cage.

\section{Data analysis}

Female fecundity (number of eggs per female) and adult mortality were statistically analyzed by two-way (food and time (day of measurement) for fecundity; food and sex for mortality) analysis of variance (ANOVA), using the general linear model (GLM) procedure of SAS $(\alpha=$ 0.05). Hatching, pupation, and emergence rates were analyzed by one-way (food) analysis of variance. Previously, normalities and homogeneity of the variances were tested using Levene test (Zar, 1999). Student Newman and Keuls test was used for comparison of means among treatment ( $P \leq 0.05$ level of significance). All statistical analyses were carried out using SAS (version 9.2).

\section{Results}

Fecundity of M. domestica females

The number of eggs laid by female varied with the type of food (DF $=4 ; F=126.90 ; P<0.0001)$ and time (number of days after emergence) $(\mathrm{DF}=7 ; F=256.13 ; P<0.0001)$ with a significant type of food/time interaction $(\mathrm{DF}=28$; $F=34.27 ; P<0.0001$ ). Oviposition started the 3rd day after emergence, and the highest daily fecundity rates were reached between 6 and 8 days after emergence, with a peak at 98 eggs per female on average for flies fed with pineapple on day 8 (Table 2). Females of $M$. domestica fed with milk + sugar mixture laid on average 325 eggs/female during the first 10 days after emergence. This is statically superior ( $\mathrm{DF}=4, F=38.91, P<0.0001)$ to fecundities obtained with flies fed with honey (179), papaya (210), and banana (151). However, there was no significant difference with the number of eggs (321) produced by female fed with pineapple (Table 2).

Table 2 Evolution of fecundity (means \pm standard deviation) of $M$. domestica females according to type of food and time

\begin{tabular}{|c|c|c|c|c|c|c|c|c|c|c|c|}
\hline \multicolumn{12}{|c|}{ Number of eggs laid per female } \\
\hline Diets & $\begin{array}{l}\text { Day } \\
1-2\end{array}$ & Day 3 & Day 4 & Day 5 & Day 6 & Day 7 & Day 8 & Day 9 & Day 10 & $\begin{array}{l}\text { Fisher } F \\
\text { probability }\end{array}$ & $\begin{array}{l}\text { Total } \\
\text { fecundity }\end{array}$ \\
\hline Pineapple & 0 & $\begin{array}{l}0.65 \pm \\
0.05 \mathrm{Dd}\end{array}$ & $\begin{array}{l}10.42 \pm \\
0.16 \mathrm{Cd}\end{array}$ & $\begin{array}{l}11.27 \pm \\
0.53 \mathrm{Cd}\end{array}$ & $\begin{array}{l}64.08 \pm \\
7.04 \mathrm{Bb}\end{array}$ & $\begin{array}{l}40.81 \pm \\
4.58 \mathrm{Ac}\end{array}$ & $\begin{array}{l}97.93 .20 \pm \\
4.30 \mathrm{Aa}\end{array}$ & $\begin{array}{l}44.41 \pm \\
1.55 \mathrm{BC}\end{array}$ & $\begin{array}{l}37.00 \pm \\
3.12 \mathrm{AC}\end{array}$ & $\begin{array}{l}81.03 \\
P<0.0001\end{array}$ & $\begin{array}{l}320.82 \pm \\
25.39 \mathrm{~A}\end{array}$ \\
\hline Banana & 0 & $\begin{array}{l}7.42 \pm \\
0.20 \mathrm{Bd}\end{array}$ & $\begin{array}{l}15.09 \pm \\
0.75 B C\end{array}$ & $\begin{array}{l}16.62 \pm \\
1.14 \mathrm{BC}\end{array}$ & $\begin{array}{l}19.13 \pm \\
0.90 \mathrm{Cbc}\end{array}$ & $\begin{array}{l}15.21 \pm \\
0.81 C c\end{array}$ & $\begin{array}{l}36.86 \pm \\
3.93 \mathrm{Ca}\end{array}$ & $\begin{array}{l}23.56 \pm \\
1.56 \mathrm{Da}\end{array}$ & $\begin{array}{l}17.32 \pm \\
1.59 C \mathrm{c}\end{array}$ & $\begin{array}{l}24.64 \\
P<0.0001\end{array}$ & $\begin{array}{l}151.21 \pm \\
4.93 C\end{array}$ \\
\hline $\begin{array}{l}\text { Milk + } \\
\text { sugar }\end{array}$ & 0 & $\begin{array}{l}9.65 \pm \\
0.47 \mathrm{Ae}\end{array}$ & $\begin{array}{l}22.62 \pm \\
1.09 \text { Acd }\end{array}$ & $\begin{array}{l}18.06 \pm \\
0.91 \mathrm{Bd}\end{array}$ & $\begin{array}{l}84.64 \pm \\
5.82 \mathrm{Aa}\end{array}$ & $\begin{array}{l}31.66 \pm \\
2.67 \mathrm{BC}\end{array}$ & $\begin{array}{l}62.84 \pm \\
3.35 \mathrm{Bb}\end{array}$ & $\begin{array}{l}68.01 \pm \\
2.70 \mathrm{Ab}\end{array}$ & $\begin{array}{l}27.34 \pm \\
2.02 \mathrm{Bcd}\end{array}$ & $\begin{array}{l}90.82 \\
P<0.0001\end{array}$ & $\begin{array}{l}324.81 \pm \\
16.71 \mathrm{~A}\end{array}$ \\
\hline Honey & 0 & $\begin{array}{l}5.19 \pm \\
0.34 \mathrm{Ce}\end{array}$ & $\begin{array}{l}9.37 \pm \\
0.26 C \mathrm{e}\end{array}$ & $\begin{array}{l}24.72 \pm \\
1.00 A c\end{array}$ & $\begin{array}{l}64.63 \pm \\
3.60 \mathrm{Ba}\end{array}$ & $\begin{array}{l}22.29 \pm \\
0.93 C c\end{array}$ & $\begin{array}{l}29.52 \pm \\
0.82 \mathrm{Cb}\end{array}$ & $\begin{array}{l}8.62 \pm \\
0.47 \mathrm{Ee}\end{array}$ & $\begin{array}{l}14.66 \pm \\
0.22 \mathrm{Cd}\end{array}$ & $\begin{array}{l}183.24 \\
P<0.0001\end{array}$ & $\begin{array}{l}178.99 \pm \\
5.29 B C\end{array}$ \\
\hline Papaya & 0 & $\begin{array}{l}4.91 \pm \\
0.21 \mathrm{Cf}\end{array}$ & $\begin{array}{l}14.36 \pm \\
1.18 \mathrm{Ae}\end{array}$ & $\begin{array}{l}15.26 \pm \\
1.28 \mathrm{Be}\end{array}$ & $\begin{array}{l}25,73 \pm 1 \\
77 \mathrm{Cd}\end{array}$ & $\begin{array}{l}31.13 \pm \\
0.78 \mathrm{Bcd}\end{array}$ & $\begin{array}{l}43.66 \pm \\
2.77 \mathrm{Ca}\end{array}$ & $\begin{array}{l}39.28 \pm \\
1.69 \mathrm{Cab}\end{array}$ & $\begin{array}{l}35.85 \pm \\
3.43 \mathrm{Abc}\end{array}$ & $\begin{array}{l}51.40 \\
P<0.0001\end{array}$ & $\begin{array}{l}210.18 \pm \\
7.78 \mathrm{~B}\end{array}$ \\
\hline $\begin{array}{l}\text { Fisher F } \\
\text { Probability }\end{array}$ & - & $\begin{array}{l}131.92 \\
P< \\
0.0001\end{array}$ & $\begin{array}{l}42.31 \\
P<0.0001\end{array}$ & $\begin{array}{l}23.88 \\
P<0.0001\end{array}$ & $\begin{array}{l}39.11 \\
P<0.0001\end{array}$ & $\begin{array}{l}15.87 \\
P<0.0001\end{array}$ & $\begin{array}{l}44.58 \\
P<0.0001\end{array}$ & $\begin{array}{l}165.34 \\
P<0.0001\end{array}$ & $\begin{array}{l}18.81 \\
P<0.0001\end{array}$ & & $\begin{array}{l}31.57 \\
P<0.0001\end{array}$ \\
\hline
\end{tabular}




\section{Mortality of $M$. domestica adults}

Cumulative mortality during the 10 days of observation is shown in Fig. 1 . Sex (DF $=4 ; F=0.24$ to $2.21 ; P=$ 0.08 to 0.91 ) did not affect the mortality rate of housefly adults, in contrast to the food type, which significantly affected mortality every day of observation $(\mathrm{DF}=4 ; F=$ 3.41 to $28.29 ; P=0.0154$ to $P<0.0001$ ) except the third $(\mathrm{DF}=4 ; F=1.49 ; P=0.22)$ and fourth $(\mathrm{DF}=4 ; F=$ $1.81 ; P=0.14)$ days. On the 1 st day, no mortality was registered. Mortality started to increase extensively on the 5th day. On the last day (10th), flies fed on local fruits (pineapple, papaya, and banana) statistically recorded higher mortality (> 50\%) than those fed on conventional foods (milk + sugar and honey). Flies fed with pineapple registered the highest cumulative mortality (63\%) after 10 days and those fed with honey the lowest (27\%) (Fig. 1).

\section{Hatching rate of eggs}

The hatching of housefly eggs was not affected by the quality of food with which females were fed $(\mathrm{DF}=4$; $F=1.67 ; P=0.1895)$. The highest hatching rate was obtained with eggs from females fed with milk + sugar $(89 \%)$ while the lowest $(80 \%)$ was recorded with eggs from flies fed with banana (Fig. 2).

\section{Pupation rate of $\boldsymbol{M}$. domestica larvae}

Figure 3 shows the cumulative pupation rate of house fly larvae after egg incubation. Pupation started the 5th day after egg incubation. The pupation rate of larvae from different rearing systems was significantly influenced by the type of food (DF $=4 ; F=3.81$ to $10.77 ; P=0.0149$ to $P^{<}$ $0.0001)$ all observation days except the 9th day $(\mathrm{DF}=4 ; F$ $=0.88 ; P=0.4903$ ) when over $95 \%$ of the larvae had pupated in all food rearing systems. Pupation was faster in larvae fed with milk + sugar than in the other rearing systems (e.g., for the 7th day: $\mathrm{DF}=4 ; F=7.09 ; P=0.0006$ ).

\section{Emergence rate of $M$. domestica adults}

The cumulative emergence rate of $M$. domestica adults is shown in Fig. 4. Emergence of adults started 4 days after pupation. There were strong statistical differences in the emergence rate of $M$. domestica adults among food types (DF $=4 ; F=2.61$ to $32.00 ; P=0.0600$ to $P<$ 0.0001 ) all days except the last day (8th day: $\mathrm{DF}=4 ; F=$ $0.81 ; P=0.5298$ ) when the emergence rate was over $94 \%$ for all rearing systems. The shortest pupation time was observed in flies fed with milk + sugar and pineapple.

\section{Discussion}

Feeding is an important parameter in conventional insect breeding systems and has a significant influence on

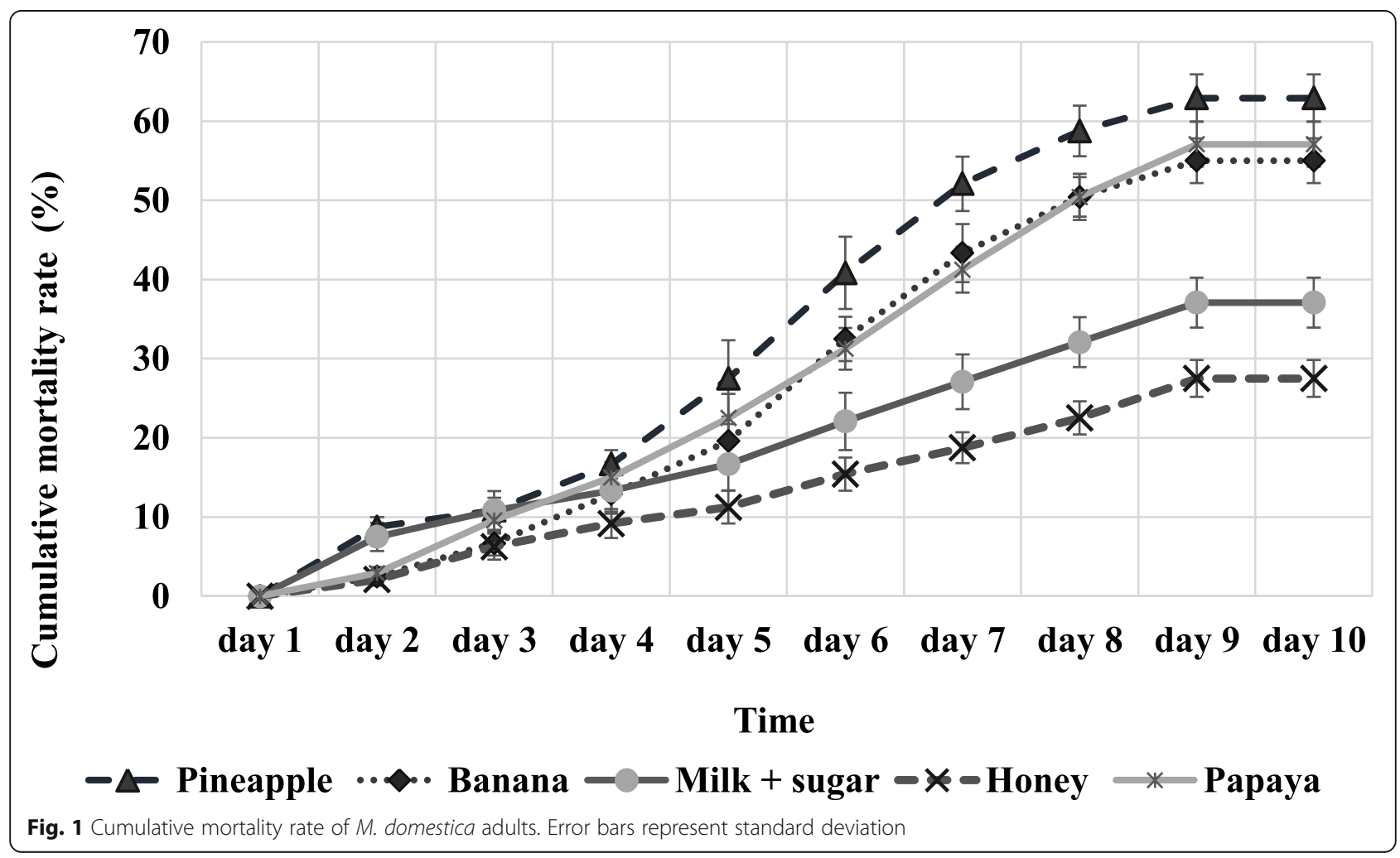




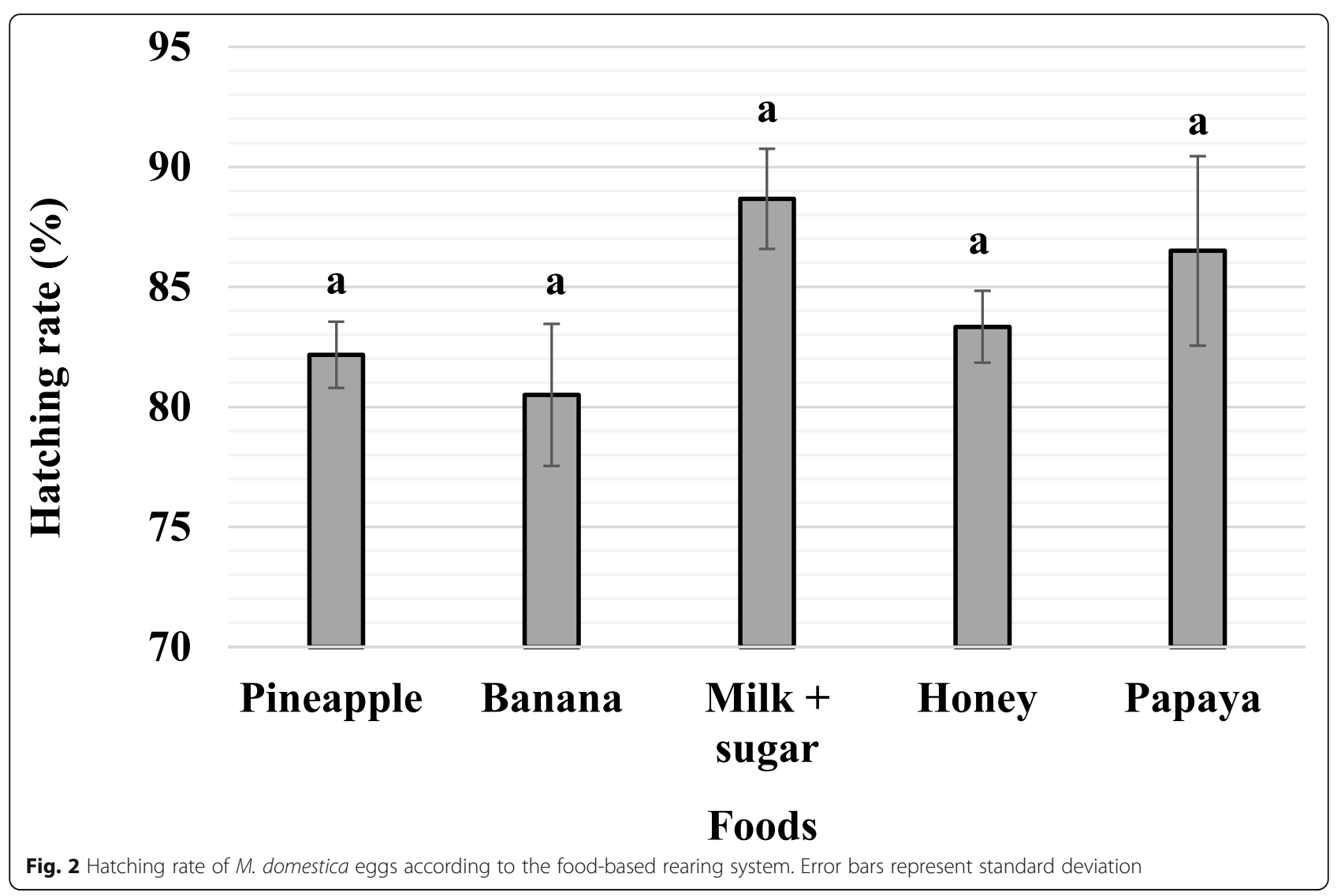

the productivity of insects, as shown by our results on $M$. domestica. The mixture of milk + sugar and pineapple induced the highest daily fecundity rates. Pastor et al. (2011) demonstrated that a well-balanced diet is necessary for successful reproduction. Also, according to Strangways-Dixon (1961), M. domestica needs both sugar and protein for egg production and the ratio sugar/protein changes with the stage of development. The number of eggs obtained per female of $M$. domestica fed on milk + sugar mixture in this study (40.60 egg/female/day) is somewhat different from that reported by other authors for the same diet. Lysyk (1991) reported a maximum laying rate in a field experiment of 11.4 eggs per female per day. (Fletcher et al. 1990) estimated the lifetime fecundity of $M$. domestica female at 433.1 eggs at $25^{\circ} \mathrm{C}$ when fed with a dilute solution of evaporated milk and granular sugar (324.81 eggs/female during 10 days in our study). Several factors can explain the difference between our results obtained and those of these authors: differences in fly strains, rearing techniques and conditions, quality and quantity of milk powder used, etc. In addition, these authors report a different number of flies (more than 100) in experimental cages, which may also have influenced their results. Pastor et al. (2011) observed that fly density is negatively correlated with fecundity; nevertheless, they recommend rearing at high density (14.2 $\mathrm{cm}^{3}$ per fly) to increase the efficiency and productivity of the fly production system. More generally, the number of eggs a fly female can oviposit is influenced by environmental temperature and humidity, quantity and quality of larval diet, quantity and quality of adult diet, mating, adult population density, age of flies, oviposition substrate, photoperiod, and genetic factors (see a discussion of these factors in Pastor et al. (2015)).

Although, in our study, the best results were obtained with the conventional milk and sugar diet; the different local fruits used in our experiments showed very satisfactory results. Especially, flies fed on pineapple showed similar egg-laying performances with those fed on the milk and sugar mixture. These results are particularly important since they meet the objective pursued by this study, i.e., finding alternatives to replace expensive conventional food with a local food, easily accessible and cheaper. As the variety of pineapple used in our experiments is naturally high in sugar, we could think that the sugar level in the fly diet plays an important role in the fecundity of $M$. domestica females. For Sun et al. (2002) and Pastor et al. (2011), oviposition of $M$. domestica is strongly influenced by several factors such as the quality of protein source that determines the volume of eggs produced. The work by Beard and Sands (1973) on the comparison of the non-protein diet with diets enriched in protein supplements revealed that the addition of 

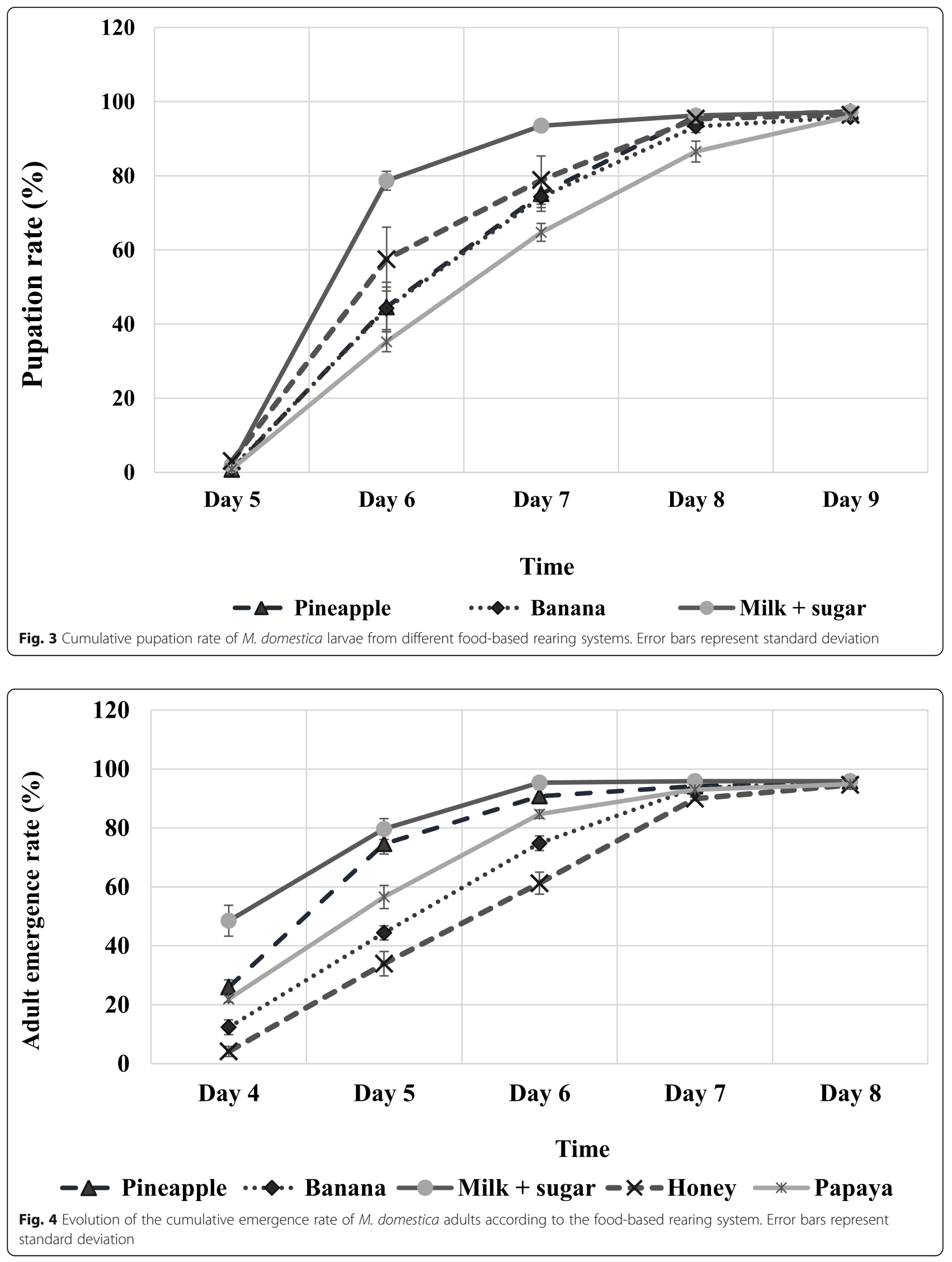
protein to the diet of $M$. domestica adults resulted in a substantial increase in the production of eggs. This explains the high fertility of flies fed on the milk + sugar mixture. Indeed, this food has the highest levels of carbohydrates and proteins. However, the high potential of pineapple is surprising because in terms of energy and protein content, it is only fourth behind banana and honey. As the protein content plays an important role in female fecundity (Lardies et al. 2004), it is difficult to conceive that pineapple showed a high potential compared to bananas, which are richer in protein. However, the nature of the proteins present in these different fruits could explain the differences observed in fly fecundity. Furthermore, Shipp and Osborn (1967) showed that the physical state in which food is offered to adult flies is also important. In our case, the gelatinous nature of the mixed banana diet was different from the pineapple diet, which forms a homogeneous paw, and may be less suitable for flies. Another potential replacement of milk in fly production systems is smashed fly larvae, which also contain a high level of proteins and are very efficient in rural fly production systems, as shown by Maciel-Vergara (2014).

The study of the effect of the different types of adult food on the pupation rate and time of the progeny reveals that more than $50 \%$ of the larvae have pupated the 7th day after egg incubation. Several authors have reported that pupation is time-dependent and the nature of larvae development substrate can influence the pupation rate of $M$. domestica larvae (Loa 2000; Pastor et al. 2011). Their conclusions thus confirm our results, which highlighted that the pupation of larvae and the emergence of adults increased with time depending the type of food until the last day where there is no food influence on pupation and emergence rates. Robertson (2015) claimed on their side that the pupal stage usually lasts about 6-7 days and is influenced not only by substrate temperature but also by ambient temperature.

The results also showed that the mortality rate of adults reached $50 \%$ the 8th day except for flies fed on milk + sugar and honey which mortality rate remained lower. Indeed, these two foods are characterized by a high sugar content, thus promoting the longevity of flies. Pastor et al. (2011) report that adult houseflies fed with the milk + sugar mixture were still able to lay at 34 days and have a low mortality rate. However, for Berberian et al. (1971) and Golubeva (1984), fly mortality may be related to the number of eggs laid, which depends on their diet and the availability of suitable substrate for laying and eventually on local climatic factors. Flies fed on pineapple showed the highest mortality rates on the 8th day of observation. This high mortality of flies fed on pineapple, combined with their high fecundity and low protein and carbohydrate content, seems to corroborate the observations of for Berberian et al. (1971) and Golubeva (1984).
Finally, it must be noted that these results were carried out under quasi natural conditions to mimic potential fly larvae production systems that could be set up in rural areas in Benin. We do not think that the variable climatic conditions experienced during the trials influenced the comparison between the adult food treatments because these were carried out in parallel. However, it is clear that climatic conditions influence fecundity, egg hatching mortality, and development (Fletcher et al. 1990; Kenis et al. 2018; Pastor et al. 2015; Zhemchuzhina and Zvereva, 1985) and, thus, the absolute data of our studies on these biological parameters have to be considered with caution. Similar trials should be repeated in other agroecological zones to better understand the effect of natural climatic factors on house fly rearing systems in West Africa.

\section{Conclusions}

The establishment of a controlled rearing system of $M$. domestica in a perspective of maggot production in Benin motivated this experiment which led to quite satisfactory conclusions. Thus, the evaluation of the nutritional potential of five types of food revealed that flies fed with pineapple and milk + sugar showed the highest fecundity of $M$. domestica females. This study showed that pineapple can be used to feed $M$. domestica instead of the conventional and more expensive foods (honey and milk + sugar mixture) without major impact on the fecundity of females.

\section{Abbreviations \\ ANOVA: Analysis of variance,; GLM: General linear model; P: Probability; DF: Degree of Freedom; F: Fisher value}

\section{Acknowledgements}

This study was carried out as part of the project IFWA-Sustainable use of insects to improve livestock production and food security in small holder farms in West Africa, funded by the Swiss Agency for Development and Cooperation and the Swiss National Science Foundation, in the framework of the Swiss Programme for Research on Global Issues for Development (R4D). MK was partly funded through the CABI Development Fund (supported by contributions from the Australian Centre for International Agricultural Research, the UK's Department for International Development, and others).

\section{Authors' contributions}

HG conceived and designed the experiments, performed the bioassay, analyzed and interpreted the data, and wrote the manuscript. HAA performed the bioassay, collected and interpreted the data. ETZB suggested, planned, and designed the study and contributed to manuscript correction. MK suggested the study and contributed to manuscript correction. CAAMC suggested the study and contributed to manuscript correction. GAM contributed to the manuscript correction. All authors read and approved the final manuscript.

\section{Funding}

This study was funded by Insect as Feed in West Africa (IFWA) Project. IFWA Project was funded by the Swiss Agency for Development and Cooperation and the Swiss National Science Foundation, in the framework of the Swiss Programme for Research on Global Issues for Development (R4D).

Availability of data and materials

Data will not be shared, only by request from the corresponding author. 


\section{Ethics approval and consent to participate}

Not applicable.

\section{Consent for publication}

Not applicable.

\section{Competing interests}

The authors declare that they have no competing interests.

\section{Author details}

${ }^{1}$ Laboratory of Agricultural Entomology (LEAg), Faculty of Agronomic Sciences, University of Abomey-Calavi, Abomey-Calavi, Republic of Benin. ${ }^{2} \mathrm{CABI}$, Rue des Grillons 1, 2800 Delémont, Switzerland. ${ }^{3}$ Laboratory of Aviculture and Zoo-economy Research, Faculty of Agronomic Sciences, University of Abomey-Calavi, Abomey-Calavi, Republic of Benin. ${ }^{4}$ Laboratory of Zootechny, Veterinary and Fishery research, CRA Agonkanmey, National Institute of Agricultural Researches (INRAB), Abomey-Calavi, Republic of Benin.

Received: 12 March 2020 Accepted: 26 June 2020

Published online: 16 July 2020

\section{References}

Aniebo, A. O., Erondu, E. S., \& Owen, O. J. (2008). Proximate composition of housefly larvae (Musca domestica) meal generated from mixture of cattle blood and wheat bran. Livestock Research for Rural Development, 20(12).

Beard, R. L., \& Sands, D. C. (1973). Factors affecting degradation of poultry manure by flies. Environmental Entomology, 2, 801-806.

Berberian, P. A., Rockstein, M., \& Gray, F. H. (1971). The effect of egg laying on the longevity of the adult female house fly, Musca Domestica, L. Journal of gerontology, 26, 485-489.

Bong, L.-J., Neoh, K.-B., Lee, C.-Y., \& Jaal, Z. (2014). Effect of diet quality on survival and reproduction of adult Paederus fuscipes (Coleoptera: Staphylinidae). Journal of medical entomology, 51, 752-759.

Charlton, A., Dickinson, M., Wakefield, M., Fitches, E., Kenis, M., Han, R., ... Devic, E. (2015). Exploring the chemical safety of fly larvae as a source of protein for animal feed. Journal of Insects as Food and Feed, 1, 7-16.

Čičková, H., Newton, G. L., Lacy, R. C., \& Kozánek, M. (2015). The use of fly larvae for organic waste treatment. Waste management, 35, 68-80.

Čičková, H., Pastor, B., Kozánek, M., Martínez-Sánchez, A., Rojo, S., \& Takáč, P. (2012). Biodegradation of pig manure by the housefly, Musca domestica: a viable ecological strategy for pig manure management. Plos one, 7, e32798.

Delvare, G., \& Aberlenc, H.P. (1986). Les insectes d'Afrique et d'Amerique tropicale. Stage CNEARC/FIC-Faunistique: Clés pour la reconnaissance des familles.

Drew, D., \& Pieterse, E. (2015). Markets, money and maggots. Journal of Insects as Food and Feed, 1, 227-231.

Fasakin, E. A., Balogun, A. M., \& Ajayi, O. O. (2003). Evaluation of full-fat and defatted maggot meals in the feeding of clariid catfish Clarias gariepinus fingerlings. Aquaculture Research, 34, 733-738.

Fletcher, M., Axtell, R., \& Stinner, R. (1990). Longevity and fecundity of Musca domestica (Diptera: Muscidae) as a function of temperature. Journal of medical entomology, 27, 922-926.

Golubeva E (1984) Fertility of the housefly Musca domestica L. developing on organic wastes (under conditions of individual rearing) Meditsinskaia parazitologiia i parazitarnye bolezni:40-44

Hogsette JA, Farkas R, Thuróczy C (2001) Hymenopteran pupal parasitoids recovered from house fly and stable fly (Diptera: Muscidae) pupae collected on livestock facilities in southern and eastern Hungary Environmental Entomology 30:107-111

Kenis, M., Bouwassi, B., Boafo, H., Devic, E., Han, R., Koko, G., ... Roffeis, M. (2018). Small-Scale Fly Larvae Production for Animal Feed, (pp. 239-261). In: Edible Insects in Sustainable Food Systems. Springer.

Kenis, M., Koné, N., Chrysostome, C., Devic, E., Koko, G., Clottey, V., ... Mensah, G. (2014). Insects used for animal feed in West Africa Entomologia, 2.

Koné, N., Sylla, M., \& Nacambo, S. (2017). Kenis M. Production of house fly larvae for animal feed through natural oviposition Journal of Insects as Food and Feed, 3, 177-186.

Lardies, M. A., \& Carter, M. J. (2004). Bozinovic F. Dietary effects on life history traits in a terrestrial isopod: the importance of evaluating maternal effects and tradeoffs Oecologia, 138, 387-395.
Loa, C. (2000). Production et utilisation contrôlées d'asticots. Tropicultura, 18, 215219.

Lysyk, T. (1991). Modelling oviposition of the house fly (Diptera: Muscidae) The. Canadian Entomologist, 123, 345-352.

Maciel-Vergara G (2014) Improvement of a house fly maggot production system for animal feed in Ghana. University of Catania, Italy, and University of Copenhagen, Denmark

Newton, G., Sheppard, D., Watson, D., Burtle, G., Dove, C., \& Tomberlin, J. (2005). Thelen $E$ The black soldier fly, Hermetia illucens, as a manure management/ resource recovery tool, (pp. 5-7). In: Symposium on the state of the science of Animal Manure and Waste Management.

Newton L, Sheppard C, Watson DW, Burtle G, Dove R (2005) Using the black soldier fly, Hermetia illucens, as a value-added tool for the management of swine manure Animal and Poultry Waste Management Center, North Carolina State University, Raleigh, NC 17

Ortiz, J. C., Ruiz, A. T., Morales-Ramos, J., Thomas, M., Rojas, M., Tomberlin, J., .. Jullien, R. (2016). Insect mass production technologies, (pp. 153-201). In: Insects as Sustainable Food Ingredients. Elsevier.

Pastor, B., Cicková, H., Kozánek, M., Martínez-Sánchez, A., Takác, P., \& Rojo, S. (2011). Effect of the size of the pupae, adult diet, oviposition substrate and adult population density on egg production in Musca domestica (Diptera: Muscidae). European Journal of Entomology, 108, 587.

Pastor, B., Velasquez, Y., \& Gobbi, P. (2015). Rojo S. Conversion of organic wastes into fly larval biomass: bottlenecks and challenges Journal of Insects as Food and Feed, 1, 179-193.

Pomalégni, S., Gbemavo, D., Kpadé, C., \& Kenis, M. (2017). Mensah G. Traditional use of fly larvae by small poultry farmers in Benin Journal of Insects as Food and Feed, 3, 187-192.

Pomalégni SCB, Gbemavo DSJC, Kpadé CP, Babatoundé S, Chrysostome CAAM, Koudandé OD, Kenis M, Glèlè Kakaï RL, Mensah GA (2016) Perceptions et facteurs déterminant l'utilisation des asticots dans l'alimentation des poulets locaux (Gallus gallus) au Bénin Journal of Applied Biosciences 98:9330-9343

Robertson A, Daniel W, Simon L (2015) Lutte contre la mouche domestique dans les élevages de volailles. Ministère de l'agriculture et de l'alimentation d'Ontario.

Sanou AG, Sankara F, Pousga S, Coulibaly K, Nacoulma JP, Kenis M, Clottey VA, Nacro S, Somda I (2018) Indigenous practices in poultry farming using maggots in western Burkina Faso

Scott, J. G., Alefantis, T. G., \& Kaufman, P. E. (2000). Rutz DA. Insecticide resistance in house flies from caged-layer poultry facilities Pest Management Science, 56, $147-153$.

Shipp, E., \& Osborn, A. (1967). The effect of protein sources and of the frequency of egg collection on egg production by the housefly (Musca domestica L.). Bulletin of the World Health Organization, 37, 331.

Stadlmayr B, Charrondiere U R, Addy P, Samb B, Enujiugha VN, Bayili RG, Fagbohoun EG, Smith IF, Thiam I, Burlingame, B (2010) Composition of selected foods from West Africa Food and Agriculture Organization, Rome:13-14

Strangways-Dixon, J. (1961). The Relationship Between Nutrition, Hormones and Reproduction in the Blowfly Calliphora Erythrocephala (Meig.): I. Selective Feeding in Relation to the Reproductive Cycle, the Corpus Allatum Volume and Fertilization Journal of Experimental Biology, 38, 225-235.

Sun G, Fang Y, Wang ZT, Song YJ (2002) The effect of diet and density on the fecundity of housefly in the pilot scale production of its larvae. Acta Entomol. Sin. 45: 847-850 [in Chinese, English abstract]

Wang H, Zhang Z, Czapar GF, Winkler MK, Zheng J (2013) A full-scale house fly (Diptera: Muscidae) larvae bioconversion system for value-added swine manure reduction Waste Management \& Research 31:223-231

Zar, H. J. (1999). Biostatistical Analysis, (4th ed., ). Upper Saddle River NJ: Prentice Hall Inc.

Zhemchuzhina, A. (1985). Zvereva E. Effect of some factors on the choice of a site for oviposition in housefly Musca domestica females Medskaya Parazitol, 55, $55-57$.

\section{Publisher's Note}

Springer Nature remains neutral with regard to jurisdictional claims in published maps and institutional affiliations. 